Abstracta Iranica Iranica

Revue bibliographique pour le domaine irano-aryen

Volume 32-33 | 2013

Comptes rendus des publications de 2009-2010

\title{
Rika Gyselen. Les Wahramides (273-293 A.D.) : quelques aspects de leur langage monétaire
}

\author{
Jullien Cuny
}

\section{(2) OpenEdition}

1 Journals

Édition électronique

URL : http://journals.openedition.org/abstractairanica/40502

DOI : 10.4000/abstractairanica.40502

ISSN : 1961-960X

\section{Éditeur :}

CNRS (UMR 7528 Mondes iraniens et indiens), Éditions de l'IFRI

\section{Édition imprimée}

Date de publication : 1 décembre 2013

ISSN : 0240-8910

\section{Référence électronique}

Jullien Cuny, «Rika Gyselen. Les Wahramides (273-293 A.D.) : quelques aspects de leur langage monétaire ", Abstracta Iranica [En ligne], Volume 32-33 | 2013, document 160, mis en ligne le 01 juillet 2016, consulté le 03 octobre 2020. URL : http://journals.openedition.org/abstractairanica/40502 ; DOI : https://doi.org/10.4000/abstractairanica.40502

Ce document a été généré automatiquement le 3 octobre 2020.

Tous droits réservés 


\title{
Rika Gyselen. Les Wahramides
} (273-293 A.D.) : quelques aspects de leur langage monétaire

\author{
Jullien Cuny
}

\section{RÉFÉRENCE}

Rika Gyselen. « Les Wahramides (273-293 A.D.) : quelques aspects de leur langage monétaire ». Studia Iranica, 39, 2010, p. 185-223.

1 L'accession au trône de Vahrām I ${ }^{\text {er }}$ après son frère Ohrmazd I ${ }^{\text {er }}$ ne s'est peut-être pas effectuée sans contestation. Quoi qu'il en soit, le monnayage des Wahramides montre un souci constant de légitimation: par référence au grand roi Shapur $\mathrm{I}^{\mathrm{er}}$ ou par le développement sous Vahram II d'une iconographie, probablement inspirée du monnayage romain, mettant en avant le couple royal et le prince héritier. La chronologie du monnayage montre que ce langage s'est sans doute renforcé au gré des difficultés, externes (expédition de Carus) ou internes (révolte du prince Ohrmazd) rencontrées par ce roi.

\section{AUTEURS}

\section{JULLIEN CUNY}

Conservateur de patrimoine, Lille 